\title{
原著論文
}

\section{形式概念分析と数量化理論第吕類を用いた 包含・相関関係同時可視化システムの開発}

\author{
島田 雄生*, 原田 利宣** \\ $*$ 和歌山大学大学院, $* *$ 和歌山大学
}

\section{Development of Simultaneous Inclusion and Correlation Visualization System Using Formal Concept Analysis and Quantification Theory Class III}

\author{
Yusei SHIMADA* and Toshinobu HARADA** \\ * Graduate School of Wakayama University, 930 Sakaedani, Wakayama-shi, Wakayama 640-8510, Japan \\ ** Wakayama University, 930 Sakaedani, Wakayama-shi, Wakayama 640-8510, Japan
}

\begin{abstract}
In recent years, while data mining has attracted attention, formal concept analysis has the disadvantage that although it can understand the inclusion relation between attributes, it doesn't know what kind of meaning or inclusion relation the attributes have. Therefore, in this study, the inclusion of the attributes and the visualization of the correlation are realized by combining the Hasse diagram by formal concept analysis and the layout diagram of the attribute of quantification theory type III for visualizing the meaning between the attributes. Moreover, in order to confirm usefulness of the proposed method, we developed a simultaneous visualization system of inclusion and correlation combining formal concept analysis and quantification theory type III, and evaluated the proposed method using verification data. As a result, it was confirmed that useful information that can't be obtained only by formal concept analysis or quantification theory type III can be extracted.
\end{abstract}

Keywords : Data mining, Visualization system, Conceptual construction, Formal concept analysis, Quantification theory III

\section{1. は じめに}

データマイニングとは, 収集した大量のデータを解析する ことで，項目間に見られる規則性や関連性などの利用可能な 知識を抽出する技術の総称である。特にビジネスにおいて は，収集した大量のデータを分析し，それによって得られる 知見を活用することが不可欠になりつつある [1].また， データマイニングはいまだ発展途上の分野であるが, 一方で そのニーズは非常に高まっている [2]．しかし，データマイ ニングで扱うデータが大きくなるにつれて，そこから得られ る知見も膨大なものとなるため, データマイニングにおいて は，デー夕の分析のみならず，分析結果を簡潔に表現するこ とも求められる。

このようなデータマイニングに利用される分析手法の中に 形式概念分析という分析手法がある。形式概念分析とは, ハッセ図による属性間の包含関係を主にした概念構造（概念 間の包含関係や，ある概念が他の概念にもたらす影響など）の 可視化が可能な分析手法であり，元データでは一目で把握で きないデー夕同士の関係性を直観的に可視化することができ るという特徵がある。そのため，デー夕をより理解しやすい 形にするという点において，形式概念分析は非常に優れてい る分析手法であるといえる。しかし，形式概念分析は属性間 の包含関係はわかるが，属性間でどのような意味性の中， 包含関係をもつのかはわからないという久点が存在する。
そこで本研究では，このような欠点を改善するために， 形式概念分析に数量化理論第亚類を組み合わせて, 新たな分析 手法の提案を行う。また，提案した分析手法をもとにデー夕 マイニングシステムを開発し，そのシステムを使用して実際 に分析を行い，形式概念分析のみを用いた分析結果と比較す ることで提案手法の有用性を検証する.

数量化理論第正類を用いた理由は, 属性間の意味性の視覚化 を行うことができ，この利点によって形式概念分析の欠点を補う ことができると考えられるためである。 なお，本稿は提案した 分析手法の基礎的な評価を目的としているため, 提案した手法と 形式概念分析の比較では，書籍や論文から引用した比較的簡単 な内容のデー夕を分析対象のモデルケースとして使用している.

次に，形式概念分析および数量化理論第正類に関する既存 研究を示す。

\section{（1）形式概念分析を用いた手法の提案}

酒匂らは，形式概念分析とラフ集合を用いた分析手法を 提案し，それを行うシステムを開発することで，分析手法の 有用性を検証した [3]．澤勢らは，形式概念分析を機械学習 に応用し，画像検索結果構造可視化システムを提案した [4]. 形式概念分析の技術をWebページクラスタリング手法に用い る研究もされている [5].

(2) 数量化理論第類を用いた手法の提案

森らは, 数量化理論第正類を用いてスギ花粉飛散動態の分 析を行った [6]. 向日らは, 数量化理論第正類を用いて人と 情報システムとの関係を調査した [7]. 
以上に示すとおり, 形式概念分析あるいは数量化理論第而類 単体を拡張した手法や，他の分析手法と組み合わせた手法を 提案する研究はあるが, 両者を組み合わせた手法が提案され た例はない。また，ハッセ図と布置図の双方を組み合わせて， 3 次元座標面上にグラフを描画しようと試みた例もない. 本研 究における研究領域は, これら2分野を複合したものである といえる.

\section{2. 使用する分析手法の解説}

\section{1 形式概念分析の概要}

形式概念分析は, 1982年にドイツのR.Willeによって束論 をもとにして提唱された。 この分析法は, 分析対象が持つ属 性を概念とし, 概念間の半順序関係をハッセ図によって視覚 化することができる. 形式概念分析には, 任意の名義尺度, 順序尺度を分析対象として扱うことができる点や概念間の関 係を, 数值デー夕を用いることなく表現できるため, 分析対 象がもっている情報の多様性を失わず，客観的な分析結果を 得られる点などの利点がある $[8]$.

形式概念分析は, 分析対象となるオブジェクトおよびオブ ジェクトが有する属性からなる属性表, あるいはコンテクスト 表をあつかう，表1に属性表の例として, 書籍「Introduction To Lattices And Order」より抜粋した属性表を示す [9]. 表の 左端にある「水星」,「金星」, 一,「冥王星」はサンプルと呼ば れ, 分析対象となる各惑星をあらわす。また, 表の上端にある 「大きさ」「太陽からの距離」などを属性と呼ぶ.「小」や「近い」 などの要素は属性值と呼ばれ, 各属性がとっている実際の值 を示す。

形式概念分析においては, 属性表よりもコンテクスト表 (クロス表) と呼ばれる表が用いられる場合が多い，表2に コンテクスト表の例を示す，表の左端にある「水星」，「金星」， …「冥王星」はオブジェクトと呼ばれ，分析対象となる 各惑星をあらわす。また，表の上端にある「大きさ：小」や 「距離：近い」などを属性と呼ぶ. 属性より下のセルは, オブジェクトがその列に対応する属性をもっている場合は

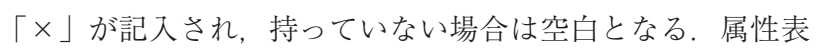
はコンテクスト表に変換することが可能であり, 表 2 のコン テクスト表は表1の属性表を変換したものである.コンテク ス卜表から求めた属性およびオブジェクトの包含関係からな る概念構造を, 概念束あるいはコンセプトラティスと呼び, 形式概念分析でははじめにこの概念束を求める。概念束は, コンテクスト表におけるすべての属性, および属性の組み合 わせに対する外延と, それに対応する内包を抽出することに よって求めることができる.

さらに，コンテクスト表中から各属性に対応する外延を抽 出し, さらにそれらの外延どうしの積集合を求めることで, オブジェクトの集合, 属性の集合, それら集合間に成り立つ 関係の $3 つ の$ 要素からなる形式概念を求める. 表 2 から求め た形式概念を表 3 に示す。ここで, 表 3 における [ ] は空集合 を意味する
表1 属性表の例

属性

\begin{tabular}{|c|c|c|c|}
\hline & 大きさ & 太陽からの距離 & 衛星の有無 \\
\hline 水星 & 小 & 近い & 無 \\
\hline 金星 & 小 & 近い & 無 \\
\hline 地球 & 小 & 近い & 有 \\
\hline 火星 & 小 & 近い & 有 \\
\hline 木星 & 大 & 遠い & 有 \\
\hline 土星 & 大 & 遠い & 有 \\
\hline 天王星 & 中 & 遠い & 有 \\
\hline 海王星 & 中 & 遠い & 有 \\
\hline 軍王星 & 小 & 遠い & 有 \\
\hline
\end{tabular}

サンプル

属性表

表2 コンテクスト表の例

属性

\begin{tabular}{|c|c|c|c|c|c|c|c|}
\hline & 小 & 中 & 大 & 近い & 遠い & 無 & 有 \\
\hline 水星 & $\times$ & & & $\times$ & & $\times$ & \\
\hline 金星 & $\times$ & & & $\times$ & & $\times$ & \\
\hline 地球 & $\times$ & & & $\times$ & & & $\times$ \\
\hline 火星 & $\times$ & & & $\times$ & & & $\times$ \\
\hline 木星 & & & $\times$ & & $\times$ & & $\times$ \\
\hline 土星 & & & $\times$ & & $\times$ & & $\times$ \\
\hline 天王星 & & $\times$ & & & $\times$ & & $\times$ \\
\hline 海王星 & & $\times$ & & & $\times$ & & $\times$ \\
\hline 冥王星 & $\times$ & & & & $\times$ & & $\times$ \\
\hline
\end{tabular}

オブジェクト

表3 形式概念の一覧

\begin{tabular}{|c|c|c|}
\hline 通番 & 内包 & 外延 \\
\hline 0 & [] & [水星,金星,地球,火星,木星,土星,天王星,海王星,冥王星 \\
\hline 1 & [有] & [地球, 火星,木星,土星,天王星,海王星,冥王星] \\
\hline 2 & [小] & [水星,金星,地球,火星,冥王星] \\
\hline 3 & [有, 小] & [地球,火星,冥王星] \\
\hline 4 & [遠し] & [木星,土星,天王星,海王星,冥王星] \\
\hline 5 & [小, 遠い] & [冥王星] \\
\hline 6 & [近い] & [水星,金星,地球,火星] \\
\hline 7 & [有, 近い] & [地球, 火星] \\
\hline 8 & [遠い, 有, 近い] & [] \\
\hline 9 & [中] & [天王星,海王星] \\
\hline 10 & [大] & [木星,土星] \\
\hline 11 & [無] & [水星,金星] \\
\hline
\end{tabular}

形式概念はそれぞれが有している外延の間に包含関係があ り, この包含関係にもとづいて, 他の形式概念を包含してい るものを上位, 他の形式概念に包含されているものを下位と した階層的順序を定めることができる。

概念束を構成する形式概念は半順序関係を持っているため ハッセ図として表すことができる, ハッセ図とは, 半順序集合 をノードとリンクによって図で示したものである、コンテク ス卜表から求めた概念束をハッセ図上に示したものが形式概 念分析の最終的な分析結果となる. 表2のコンテクスト表か ら描画したハッセ図を図1に示す。

続いて, ハッセ図の読み取り方について説明する. ハッセ図 上の各ノードは形式概念を表しており, 各形式概念はコンテ クスト表における属性とそれに属するオブジェクトからなる。 


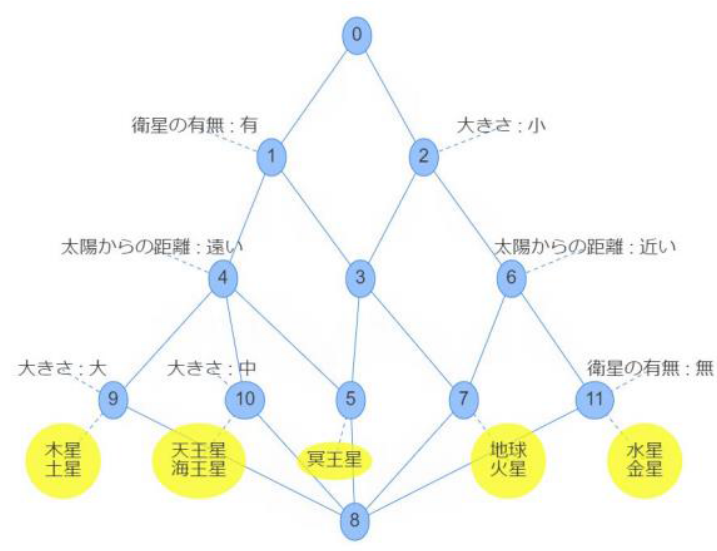

図1 ハッセ図

リンクはノードどうしの包含・被包含関係, 正確に言えば ノードに対応する形式概念の外延どうしの包含・被包含関係を 示しており，図において上位に位置しているノードが下位に位 置しているノードを包含している[3]，例えば，図1における 6番ノードと11番ノードがリンクで繋がっているが, これは 2つのノードが包含, 被包含関係にあることを示している. 図1では「太陽からの距離：近い」の属性を持つ6番ノードが 「衛星の有無：無」の属性を持つ11番ノードの上位に位置して いるため,「衛星を持たない惑星は必ず太陽からの距離が近い」 というオブジェクトの共通性にもとづいた属性間の関係性 を読み取ることができる。このように形式概念分析では, ハッセ図により属性の包含関係を読み取ることが可能である。

\section{2 数量化理論第正類の概要}

数量化理論は林知已夫によって開発された, 多次元デー夕 を数量化して分析するための手法であり，分析の目的によっ て，第 I 類から第VI類までの手法が存在する [10]．数量化理 論第而類は, 目的変数 (外的基準) がなく, 説明変数 (アイテム・ カテゴリ）が質的変数で与えられるデータに対して，数多く ある観察変数（説明変数）からいくつかの潜在変数を見出す 手法である，その潜在変数における各サンプル，カテゴリの 得点から，各サンプル，カテゴリの相関を調べることができ る. 潜在変数を見出す関係式に扔ける観察変数のウエイトを 用いて観察変数の相関を調べ，ウエイトをカテゴリスコア， サンプルの得点をサンプルスコアとして算出する.

数量化理論第正類は，分析対象となるサンプルおよびサン プルが有するアイテム・カテゴリからなるアイテム・カテゴリ 表をあつかって分析を行う。表4にアイテム・カテゴリ表の例 として，書籍「Introduction To Lattices And Order」より抜粋 したデータをアイテム・カテゴリ表に直したものを示す [9]. 表の左端にある「水星」,「金星」，、「冥王星」はサンプルと 呼ばれ，分析対象となる各惑星をあらわす。また，表の上端 にある「大きさ」,「太陽からの距離」などをアイテムと呼び, 「小」や「近い」などの要素はカテゴリと呼ばれる。サンプル がカテゴリに反応した場合, アイテム・カテゴリ表の該当する 欄に「メ」がつき，反応がなかった場合は無印となっている.
表4 アイテム・カテゴリ表

属性

\begin{tabular}{|c|c|c|c|c|c|c|c|}
\hline & \multicolumn{3}{|c|}{ 大きさ } & 太陽からの距離 & \multicolumn{2}{|c|}{ 衛星の有無 } \\
\cline { 2 - 9 } & 小 & 中 & 大 & 近い & 遠し & 無 & 有 \\
\hline 水星 & $\times$ & & & $\times$ & & $\times$ & \\
\hline 金星 & $\times$ & & & $\times$ & & $\times$ & \\
\hline 地球 & $\times$ & & & $\times$ & & & $\times$ \\
\hline 火星 & $\times$ & & & $\times$ & & & $\times$ \\
\hline 木星 & & & $\times$ & & $\times$ & & $\times$ \\
\hline 土星 & & & $\times$ & & $\times$ & & $\times$ \\
\hline 天王星 & & $\times$ & & & $\times$ & & $\times$ \\
\hline 海王星 & & $\times$ & & & $\times$ & & $\times$ \\
\hline 冥王星 & $\times$ & & & & $\times$ & & $\times$ \\
\hline
\end{tabular}

サンプル

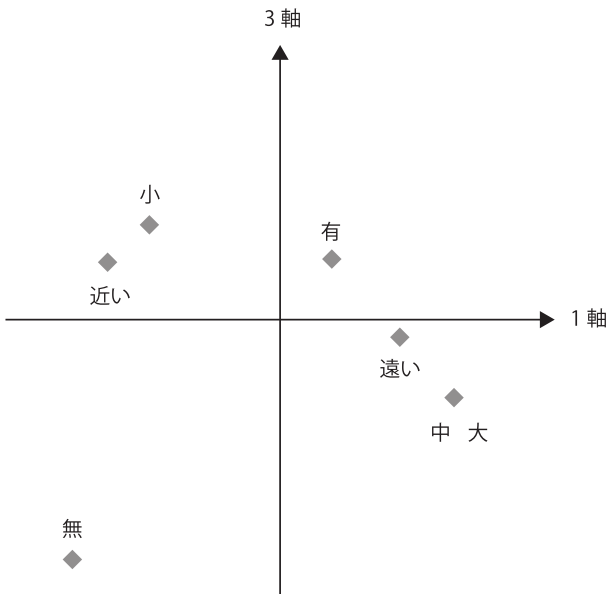

図2１-3軸のカテゴリマップ

このアイテム・カテゴリ表を用いて, サンプルスコア, カテ ゴリスコアの算出を行い，そのスコアを2次元座表面に布置 することで描画される図が布置図（サンプルスコアマップ, カテゴリスコアマップ）である。布置図を描画することで, サンプルやカテゴリの意味性の視覚化を行うことができる. 例として, 表4のアイテム・カテゴリ表を用いて数量化理論 第正類の分析を行った結果，1-3軸のカテゴリマップ (布置図) は図2のように描画された。

図2を用いて，布置図の読み取り方を説明する。はじめに， カテゴリマップから，それぞれの軸の解釈を行う。例えば, 第 1 軸は「太陽系の惑星の順番を表す軸」, 第3 軸は「衛星の有無 を表す軸」というように解釈することができる，この軸の解釈 をそれぞれの軸について行い，軸ごとに布置されているカテ ゴリ，サンプル間の距離によってそれぞれの意味性の中で相 関が求まり，布置されている位置が近いと相関があり類似性 をもつと解釈できる，例として，図2のカテゴリマップ上で, カテゴリ「小」と「近い」は近い位置に布置されていること から相関をもつことがわかる.よってこの2つのカテゴリは， 「太陽系の中でも太陽に近い惑星」という意味性の中で相関関 係にあるといえる。また，軸を変更して布置図を描画するこ とで, 様々な意味性の中での相関関係が視覚化され，デー夕 全体の相関関係を簡単に把握することができる. 
表5 形式概念分析と数量化理論第正類の特徴

\begin{tabular}{|c|l|l|}
\hline & \multicolumn{1}{|c|}{ 形式概念分析 } & \multicolumn{1}{|c|}{ 数量化理論第正類 } \\
\hline 分析対象のデータ & 属性表 & アイテム・カテゴリ表 \\
\hline 得られる分析結果 & ハッセ図 & 布置図 \\
\hline 特徵 & $\begin{array}{l}\text { すべての属性間の包含 } \\
\text { 関係の視覚化が徵の似通つたカ能 } \\
\text { やケースをゴリー } \\
\text { や見つけ出す }\end{array}$ \\
\hline
\end{tabular}

\section{3 形式概念分析と数量化理論第正類の組み合わせ}

形式概念分析と数量化理論第類の特徵を表 5 に示す. 前述のとおり，形式概念分析があつかう属性表，コンテクス 卜表は，分析対象のサンプルおよびサンプルがもつ属性から なる。 また, 数量化理論第類のあつかうアイテム・カテゴリ 表は，分析対象のサンプルおよびサンプルがもつカテゴリか らなる。これらのことにより，形式概念分析であつかうコン テクスト表と数量化理論第正類であつかうアイテム・カテゴ リ表は同じ形式で表すことができることから，同一の分析対 象に対して形式概念分析と数量化理論第正類を同時に実行す ることが可能である。本研究で提案する分析手法は，これを 利用して, 分析対象を形式概念分析および数量化理論第正類 にかけ，形式概念分析によって得られたハッセ図と数量化理 論第正類で得られたカテゴリスコアの布置図を組み合わせて 描画することで, 両方の分析結果を単一の図の上で可視化で きるようにしたものである

形式概念分析によるハッセ図は, 属性間の包含・被包含関 係を読み取ることができるが，その包含・被包含関係の意味 性までを読み取ることができない，そこで数量化理論第血類 によるカテゴリスコアの布置図を用いることで，相関関係を 持つ属性を見つけ出し，布置図の軸の解釈を行うとともにど のような意味性の中で包含関係をもつかを探ることで，属性 の包含と相関関係の視覚化を図る. 形式概念分析と数量化理 論第正類を組み合わせることで得られる利点として, 属性間 の包含関係と意味性の視覚化を同一の図上で行うことにより 形式概念分析のみでは知りえない新たな知見を見出すことが できる点が考えられる。

\section{3. 包含・相関関係同時可視化システムの解説}

\section{1 システムの概要}

前章で提案した手法をもとに, 形式概念分析と数量化理論 第正類を組み合わせた分析を行うことができる包含・相関関 係同時可視化システムを開発した。開発言語は, 高速に行列 計算ができるNumpyがライブラリで搭載されている点などか ら Python と, ブラウザ上でのグラフビジュアライゼーション に優れている点などから Javascriptを使用した。本研究で 提案する手法のフローチャートを図3に示す。本手法は, 分析対象デー夕を形式概念分析と数量化理論第而類により 分析し，それぞれの分析結果を統合する手法である。具体的 には, 同様のデータに対し，形式概念分析によるハッセ図を 描画するアルゴリズム，数量化理論第正類による布置図を 描画するアルゴリズムを実行する。 その後, それぞれ2次元

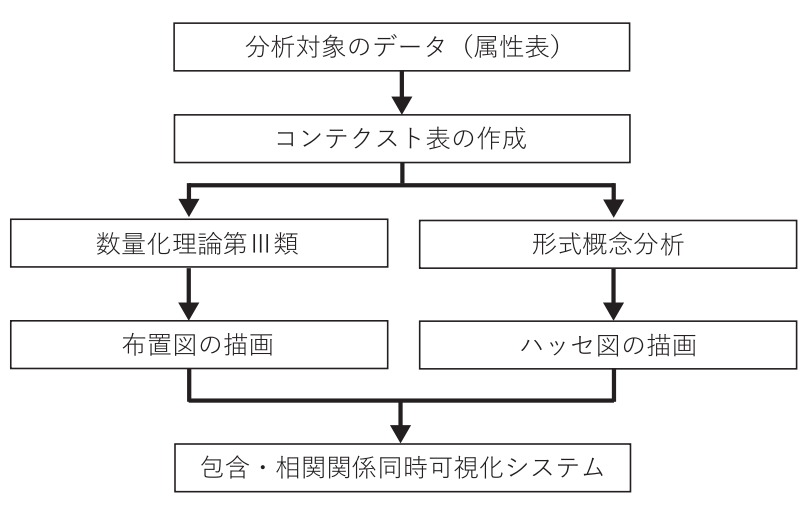

図3 提案手法のフローチャート

で描画された図同士を合成させ，x-y-z座標で表した 3 次元 空間で包含・相関関係の同時可視化を行った図を描画する. ここでは，x-z座標面を正面図，y-z座標面を側面図， $\mathrm{x}-\mathrm{y}$ 座 標面を平面図とする， $\mathrm{x}$ 軸にカテゴリスコアの $\mathrm{a}$ 軸， $\mathrm{y}$ 軸に カテゴリスコアのb軸 $(\mathrm{a}<\mathrm{b}), \mathrm{z}$ 軸にハッセ図に扮けるそれ ぞれのノードの階層の值を割り振ることによって 3 次元空間 に図を描画する。これによって，正面図，および側面図に ハッセ図, 平面図に数量化理論第正類によるカテゴリスコア の布置図が見られる。これを包含・相関関係同時可視化シス テムと呼称する。

\section{2 システムの機能}

開発したシステムを用いて表1の属性表を分析した結果を 図4に示す．図4を例に本システムの機能の説明を行う.

図4における緑色のノードは, 形式概念において, 内包, または外延が空集合であるノードを意味している。表3より， 図4での通番が「0」のノードは内包が，通番が「8」のノード は外延が空集合のため，これらのノードは緑色に着色されて いる。また，形式概念における内包を通番の若い順から見て いった場合，内包に新規の属性が含まれるものは包含・相関 関係同時可視化システムにおいて青色のノードで表される. 例えば, 図4の通番が「4」のノードは「太陽からの距離が

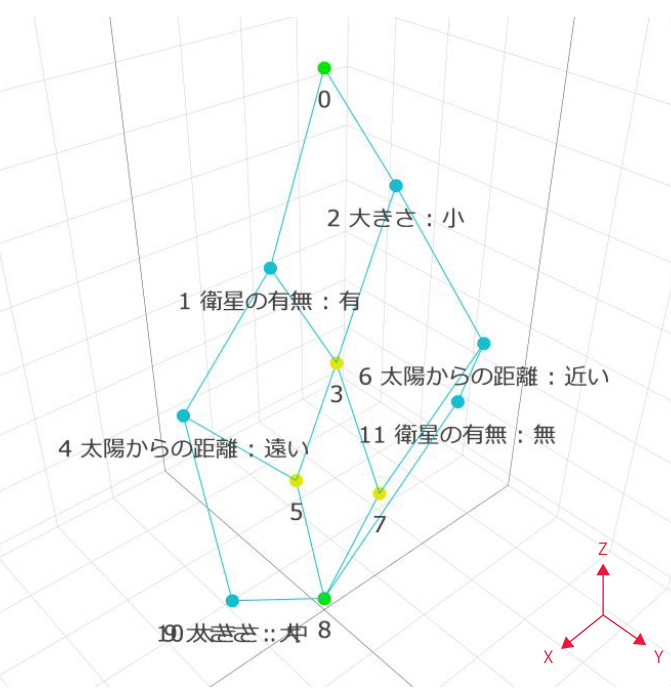

図4 包含・相関関係同時可視化システム 
遠い」という属性を持っており,「太陽からの距離が遠い」 という属性は, 表3より, 内包を通番の若い順から見ていっ た場合, 通番が「4」の内包に初めて集合を持つので,この「4」 のノードは青色で描画されている。逆に, 形式概念における 内包を通番の若い順から見ていった場合, 内包に新規の属性 が含まれないものは，包含・相関関係同時可視化システムに おいて黄色のノードで表される.

このように，ノードを色で分類した理由は，包含・相関関 係同時可視化システムの平面図にて, 青色のノードのみに着 目すると, 数量化理論第正類の結果得られたカテゴリスコア の布置図として見ることができるからである。また，包含． 相関関係同時可視化システムを正面図，および側面図から 見ると，形式概念分析の結果得られたハッセ図が見られる。 本システムの平面図を図5, 正面図を図6に示す。また，包含． 相関関係同時可視化システムは軸切り替えボタンによって, $\mathrm{x}$ 軸，y軸のカテゴリスコアの值を変更することで布置図の 軸を切り替えて表示することが可能である.

次に包含・相関関係同時可視化システムの読み取り方につ いて図4を例として説明する。図4における「大きさ：小」と 「太陽からの距離：近い」の属性を持つ2つノードに着目する. まず，図6の正面図(ハッセ図) から読み取れるように，

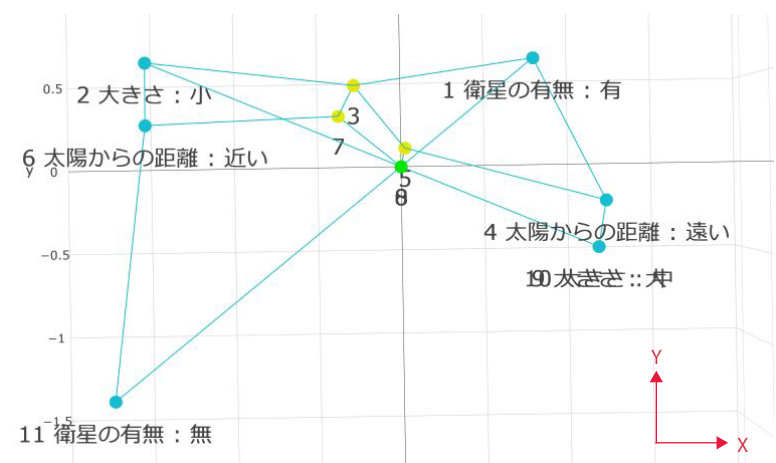

図５包含·相関関係同時可視化システムの平面図

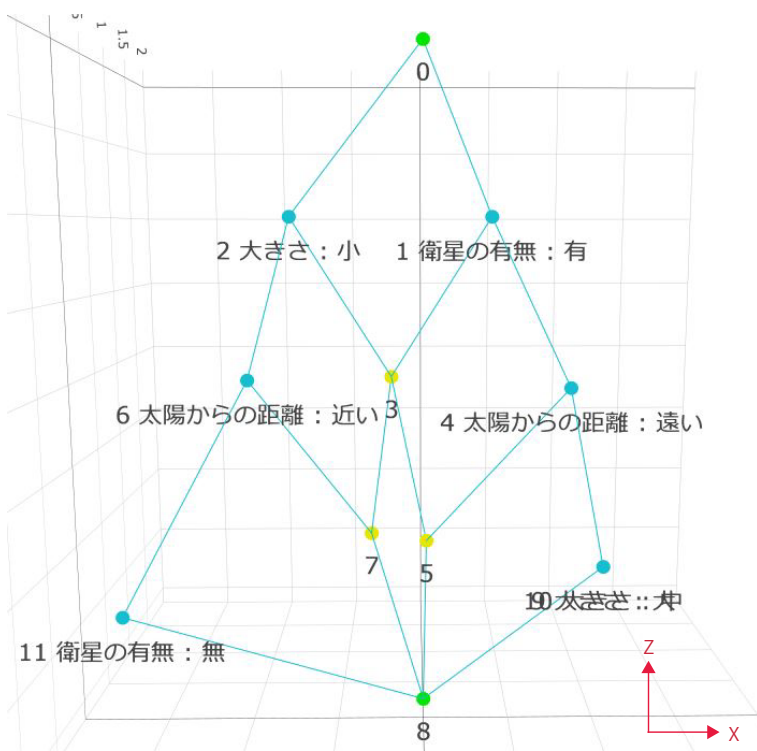

図6 包含・相関関係同時可視化システムの正面図

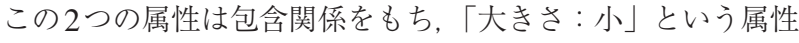
は「太陽からの距離：近い」という属性を包含している. つまり「太陽からの距離」が「近い」惑星は必ず「大きさ」が 「小さい」ことがこの図からわかる。 また，図5の平面図 (1-3 軸のカテゴリスコアの布置図）に拈いて「大きさ：小」と 「太陽からの距離：近い」の2つの属性は, 近い位置に布置 されていることから，相関をもつことがわかる．これらのこ とから,「大きさ」が「小さい」惑星と,「太陽からの距離」 が「近い」惑星は, 軸の解釈において相関関係にあり, また, ハッセ図から，太陽からの距離が近い惑星は必ず，惑星の 大きさが小さいことが読み取ることができる。したがって, これらの $2 つ の$ 属性の包含関係，相関関係の同時視覚化を行 うことができた。 このようにして，包含・相関関係同時可視 化システムを読み取ることができる。

\section{4. 提案手法を用いた分析および考察}

\section{1 分析方法の概要}

提案した分析手法の有用性を検証するため，評価実験を 行った。評価実験では，はじめに既存の論文や文献に掲載さ れているテストデータに対し，提案した手法を用いた分析を 行い，その分析結果に対して考察を行う。最後に，分析した データに対し, 形式概念分析あるいは数量化理論第正類を単 体で用いた分析結果と提案手法を用いた分析結果を比較し, 双方の分析結果の違いを検討する。提案手法を用いた分析結 果からのみ得ることができる情報があれば，今回の提案手法 は既存の分析手法からは得られない情報を抽出することがで き，有用であるといえる。

\section{2 分析結果の比較および考察}

\section{（1）スポーツカーの現状分析}

分析対象として，書籍「コンセプトデザイニング」 [11] に拈いて使用された「スポーツカーの現状分析」のデータを 使用する。このデータは，数量化理論第正類プログラムへの 入力データ例として利用された属性值データである。この 属性值データ表を表6に示す。

表6 スポーツカーの現状分析データ

\begin{tabular}{|c|c|c|c|c|c|}
\hline & エンジン & 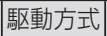 & サスペンション & タイプ & 車重クラス \\
\hline GT-R & 直6 & 4WD & マルチリンク & ノッチバック & $1.3 \mathrm{t} \uparrow$ \\
\hline シルビア & 直4 & $2 F R$ & マルチリンク & ノッチバック & $1.3 t \downarrow$ \\
\hline Z & V6 & $2 F R$ & マルチリンク & ハッチバック & $1.3 \mathrm{t} \uparrow$ \\
\hline スーブラ & 直6 & $2 F R$ & ダブルウイツシュボーン & ハッチバック & $1.3 t \uparrow$ \\
\hline セリカ & 直4 & $2 F R$ & ストラット & ハッチバック & $1.3 t \downarrow$ \\
\hline MR2 & 直4 & $2 \mathrm{MR}$ & ストラット & ノッチバック & $1.3 t \downarrow$ \\
\hline トレノ & 直4 & $2 F F$ & ストラット & ハッチバック & $1.3 t \downarrow$ \\
\hline$R \times-7$ & $\mathrm{RE}$ & $2 F R$ & マルチリンク & ハッチバック & $1.3 t \downarrow$ \\
\hline ロードス & 直4 & $2 F R$ & ストラット & ノッチバック & $1.3 t \downarrow$ \\
\hline コスモ & $\mathrm{RE}$ & $2 F R$ & ダブルウィツシュボーン & ノッチバック & $1.3 \mathrm{t} \uparrow$ \\
\hline GTO & V6 & 4WD & ダブルウィツシュボーン & ハッチバック & $1.3 \mathrm{t} \uparrow$ \\
\hline NSX & V6 & $2 \mathrm{MR}$ & ダブルウイッシュボーン & ノッチバック & $1.3 \mathrm{t} \uparrow$ \\
\hline プレリュ & 直4 & $2 F F$ & ダブルウイツシュボーン & ノッチバック & $1.3 t \downarrow$ \\
\hline CR-X & 直4 & $2 F F$ & ダブルウイッシュボーン & ノッチバック & $1.3 t \downarrow$ \\
\hline
\end{tabular}




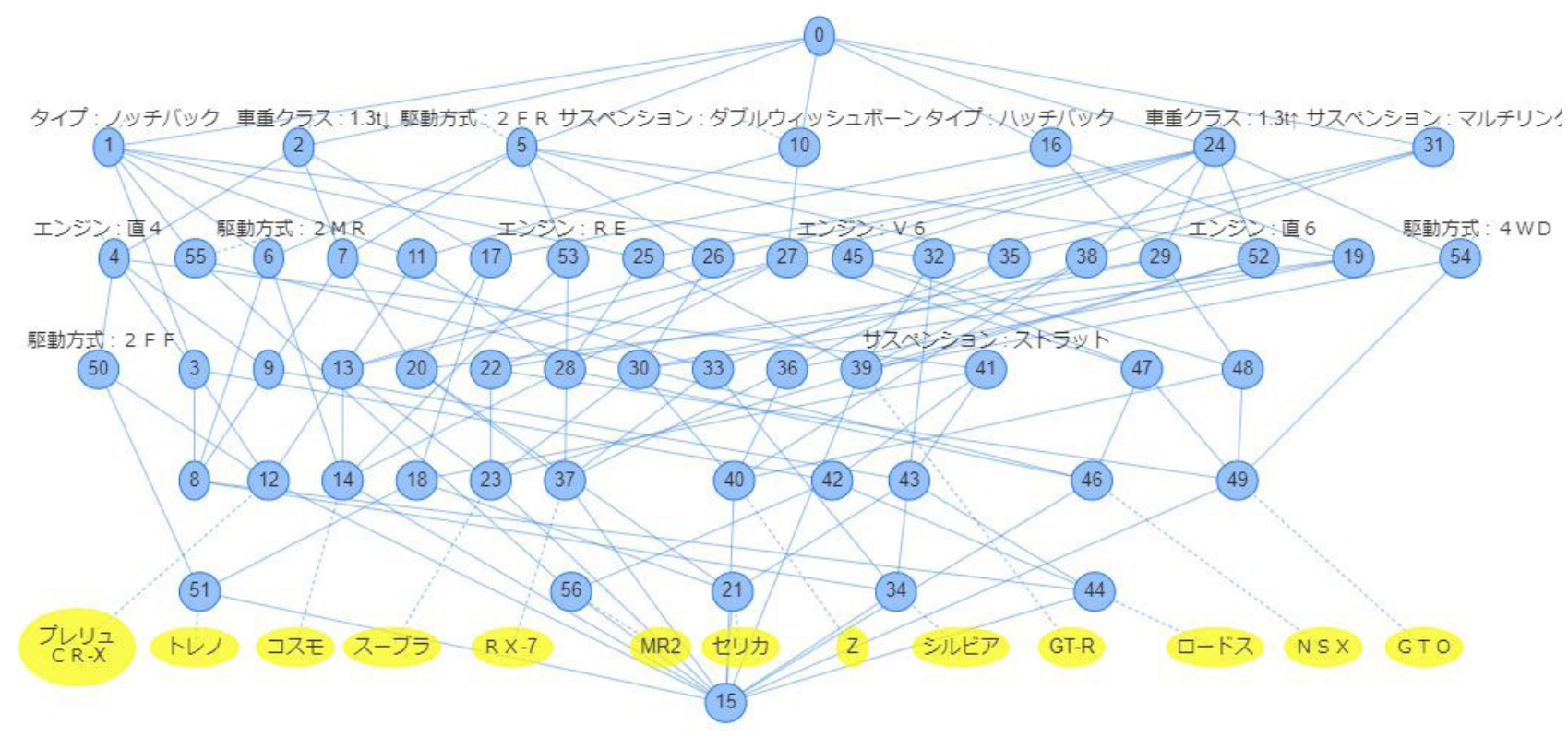

図7 ハッセ図（スポーツカーの現状分析）

\section{（i ）ハッセ図からの読み取り}

表6のデータを包含・相関関係同時可視化システムで分析 した結果得られた正面図(ハッセ図)を図7に示す。図7より, ハッセ図からいくつかの属性の包含が読み取ることができ る. 例として,「エンジン」の「RE」は「駆動方式」の「2FR」 に包含されている。これは, データ内の「エンジン」が「RE」 のスポーツカーは, 必ず「駆動方式」が「2FR」であるこ とを示している。また,「エンジン」の「V6」,「直6」, 「駆動方式」の「4WD」は「車重クラス」の「1.3t $\uparrow 」 に$ 包 含されていることから，データ内の「エンジン」が「V6」, 「直6」,「駆動方式」が「4WD」のスポーツカーは, 必ず 「車重クラス」が「1.3t 个」であることがわかる。これら以 外にも，ハッセ図により様々な包含関係を読み取ることが できる。

\section{(ii ）布置図からの読み取り}

表6のデー夕を包含・相関関係同時可視化システムで分析 した結果得られた平面図 (1-2 軸の布置図)を図8に示す. 図 8 より, カテゴリスコアの1-2 軸の布置図から軸の解釈と, それに基づくいくつかの属性の相関関係が読み取ることがで きる。軸の解勫として，第 1 軸は車格 (車のグレードの高さ) を, 第2 軸はFR系のスポーツカーか MR系のスポーツカーか を指標にされた軸であると読み取ることができる。また， 属性の相関関係の例として, 図8の右側に描画されている 「車重クラス」の「1.3t 」,「エンジン」の「直 4 , 「サスペン ション」の「ストラット」, 「駆動方式」の「2FF」は, 布置 図上で近くに布置されていることから，相関をもつことが 読み取れる。しかし，これらは第2軸の視点から見ると， 中心付近に布置されているので，第 1 軸の意味性を強くもっ ている.よって,これらの属性は, 1 軸の「車格高低」の中 の「車格が低い」という意味性の中で相関関係にあることが わかる。

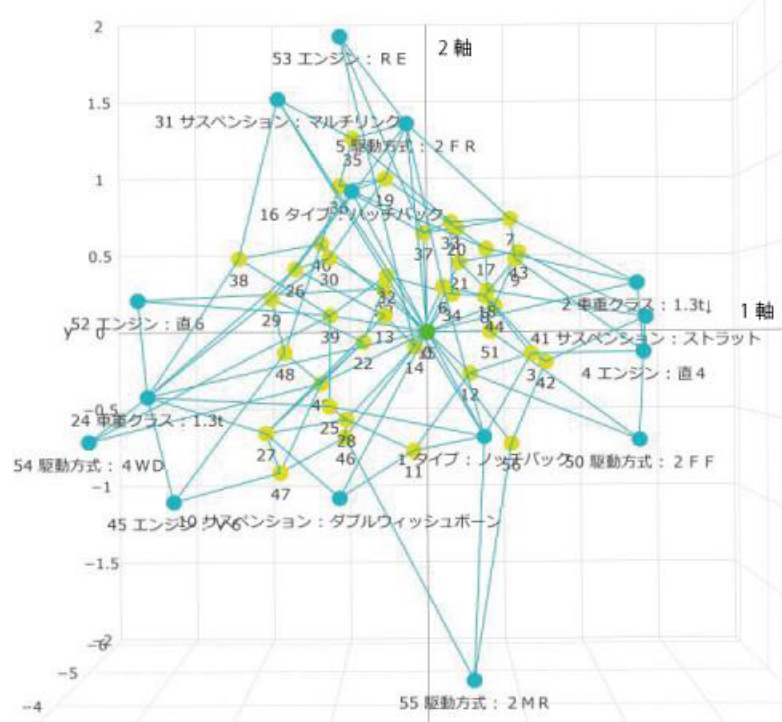

図８１-2軸の布置図 (スポーツカーの現状分析)

\section{（iii）包含をもつ属性間の意味性の読み取り}

(ii )で属性の相関関係の例として取り上げた「車重クラス」

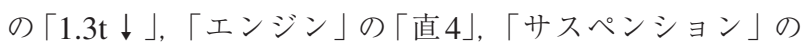
「ストラット」, 「駆動方式」の「2FF」は, ハッセ図から包含 関係をもっていることがわかる。「サスペンション」の 「ストラット」,「駆動方式」の「2FR」は「エンジン」の「直4」 に包含されており, さらに,「エンジン」の「直4」は「車重ク ラス」の「1.3t 」」に包含されている。 よって，包含・相関関 係同時可視化システムより，これらの属性は「車格高 $\Leftrightarrow$ 低」の 中の「車格が低い」という意味性の中，包含関係をもってい ると考えられる. 同様に，「駆動方式」の「2FR」と「エンジン」 の「RE」も包含関係をもっており，1-2軸の布置図上でも近い 位置（図 8 の上側）に布置されていることから，相関関係にあ ることが読み取れる。よって, 包含・相関関係同時可視化 


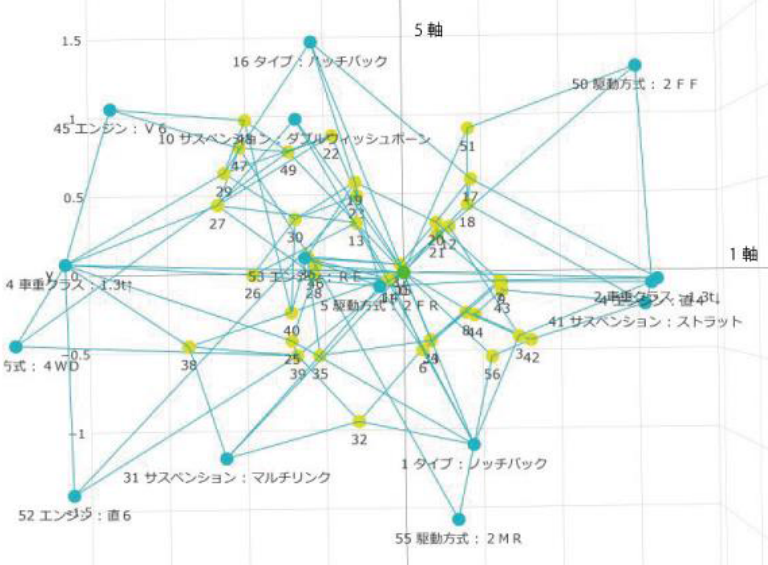

図9 1-5 軸の布置図 (スポーツカーの現状分析)

システムより，これらの属性は1軸の「車格高低」, 2 軸の $\lceil\mathrm{FR}$ 系 $\Leftrightarrow \mathrm{MR}$ 系」の中の「車格がやや高いFR系のスポーッ カー」という意味性の中，包含・相関関係をもっていると考え られる. 以上から，包含・相関関係同時可視化システムによっ て，属性間でどのような意味性の中，包含関係をもつかを 検討することができた，次に，「タイプ」の「ノッチバック」と 「駆動方式」の「2MR」の2つの属性に着目すると, この2つ の属性はハッセ図より，包含関係をもっていることがわかり， 「駆動方式」の「2MR」は「タイプ」の「ノッチバック」に 包含されていることが読み取れる。しかし, 図8の1-2軸の 布置図より,「タイプ」の「ノッチバック」と「駆動方式」の $\lceil 2 \mathrm{MR}$ は近い位置に布置されておらず，相関をもっていな いことがわかる。ここで，1-2軸で描画していた布置図を 違う軸を用いて描画してみる。 カテゴリスコアの1-5 軸の布 置図を図9に示す。図9より，カテゴリスコア1-5 軸の布置図 では「タイプ」の「ノッチバック」と「駆動方式」の「2MR」は 近い位置（図9の下側）に布置されているため, この2つの 属性は1-5軸の布置図において相関関係にあるといえる。 軸の解釈として，第 1 軸は先ほどと同じく，車格を，第 5 軸は 高出力車の中でもエンジンがV6か直6かを表す軸であると読
み取ることができる。よって，「タイプ」の「ノッチバック」 と「駆動方式」の「2MR」は，1軸の「車格高 $\Leftrightarrow$ 低」，5軸の $\lceil\mathrm{V} 6 \Leftrightarrow$ 直6」の中の「車格がやや高く, 直6のエンジンを搭載 しているスポーツカー」という意味性の中，包含関係をもっ ていると考えられる。このように，布置図の軸を変えること で，包含関係の意味性が見えてくる場合がある。これらのこ とを踏まえて, 包含・相関関係同時可視化システムから, 属性間でどのような意味性の中，包含関係をもつかを検討で きる。これは形式概念分析や数量化理論第正類単体では検討 することは難しく，提案手法の有用性を示している.

\section{(2) 自動車の形態要素とイメージの分析}

2つ目の分析対象データとして, 表7の「自動車のイメージ の分析データ」をあげる。これは，森らの研究 [12]におい てラフ集合分析に使用された決定表から決定属性を削除し, さらにその一部を抜粋したものである。

\section{（ i ）ハッセ図からの読み取り}

表7のデータを包含・相関関係同時可視化システムで分析し た結果得られた正面図 (ハッセ図) を図 10 に示す。図 10 より, ハッセ図からいくつかの属性の包含が読み取ることができ る。例として,「ラジエータグリル」の「なし」は「HLの回り 达み」の「なし」に包含されている。これは, データ内の

表7 自動車の形態要素とイメージ

\begin{tabular}{|c|c|c|c|c|c|}
\hline & 丸み & $\begin{array}{c}\text { キャビンと } \\
\text { ボデー }\end{array}$ & $\begin{array}{l}\text { ラジエータ } \\
\text { グリル }\end{array}$ & $\begin{array}{l}\text { ヘッド } \\
\text { ランプ }\end{array}$ & $\begin{array}{c}H L の \\
\text { 回り込み }\end{array}$ \\
\hline Integra & 中間 & 分割型 & なし & 丸か曲線 & なし \\
\hline Prelude & 丸い & 半融合型 & 小さい & 丸か曲線 & あり \\
\hline silvia & 中間 & 分割型 & 小さい & なし & あり \\
\hline 500 & 丸い & 半融合型 & 小さい & 丸か曲線 & あり \\
\hline Supra & 丸い & 半融合型 & なし & 丸か曲線 & なし \\
\hline Diamante & 角ばり & 分割型 & 目立つ & 丸か曲線 & あり \\
\hline Micra & 丸い & 一体化型 & 小さい & 丸か曲線 & なし \\
\hline 8501 & 中間 & 分割型 & 小さい & 長方形 & あり \\
\hline 620si & 中間 & 半融合型 & 目立つ & なし & あり \\
\hline Eldorado & 角ばり & 半融合型 & 目立つ & なし & あり \\
\hline Coupe S & 丸い & 一体化型 & 目立つ & 丸か曲線 & なし \\
\hline 456 GT & 丸い & 半融合型 & なし & \begin{tabular}{c|} 
長方形 \\
\end{tabular} & なし \\
\hline Grand AM & 中間 & 分割型 & 目立つ & 丸か曲線 & なし \\
\hline
\end{tabular}

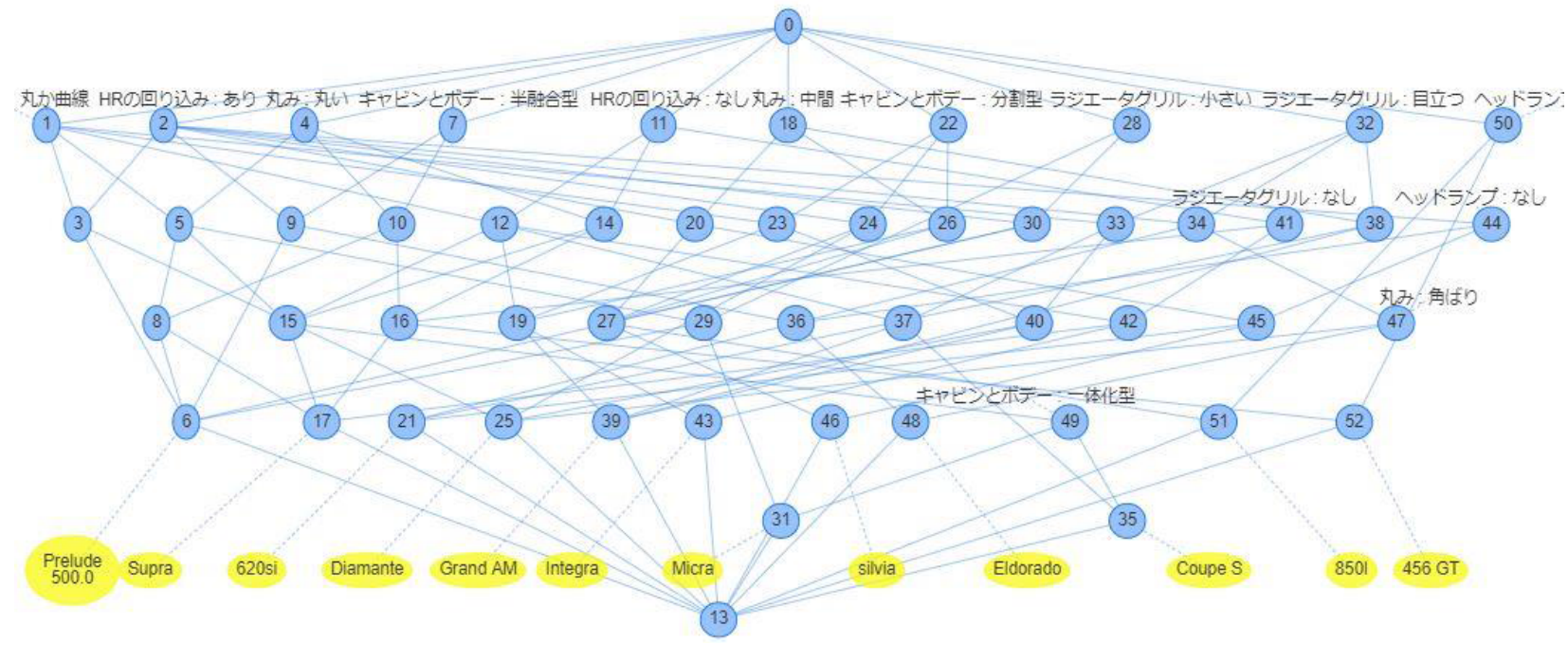

図10 ハッセ図 (自動車の形態要素とイメージ) 


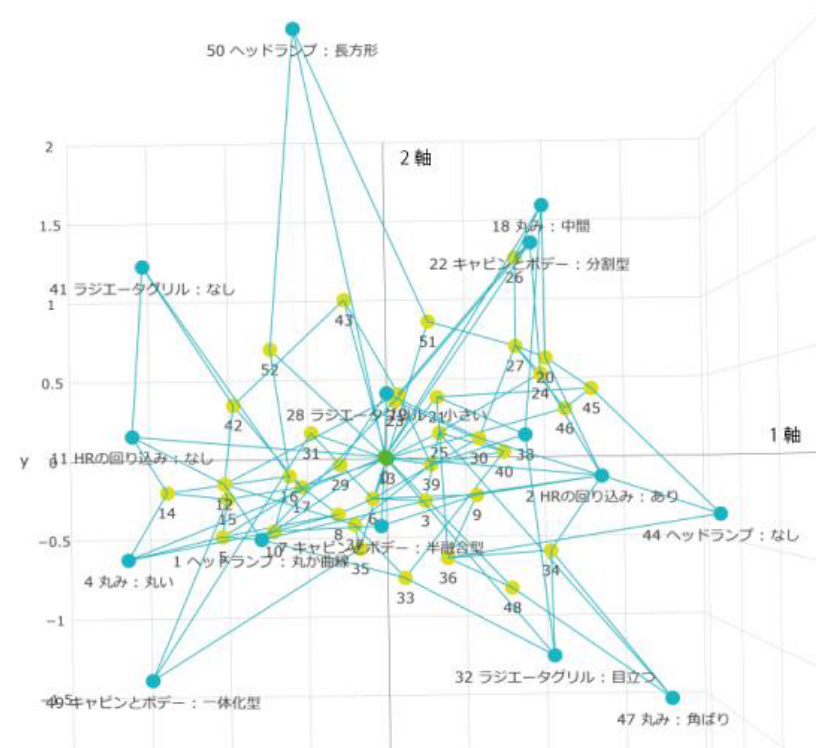

図11 1-2 軸の布置図 (自動車の形態要素とイメージ)

「ラジエータグリル」が「なし」の自動車は, 必ず「HLの回り 込み」が「なし」であることを示している。また，「丸み」の 「角ばり」は「HLの回り込み」の「あり」,「ラジエータグリル」 の「目立つ」のそれぞれに包含されていることから, デー夕内 の「丸み」が「角ばり」の自動車は, 必ず「HLの回り込み」が 「あり」かつ「ラジエータグリル」が「目立つ」という特徵を もつ。 これら以外にも, ハッセ図により様々な包含関係を読 み取ることができる。

\section{(ii ）布置図からの読み取り}

表7のデータを包含・相関関係同時可視化システムで分析 した結果得られた平面図（1-2軸の布置図）を図11に示す。 図11より, カテゴリスコアの1-2 軸の布置図から軸の解釈と, それに基づくいくつかの属性の相関関係が読み取ることがで きる. 軸の解釈として, 第1軸はスポーツカー系か乗用車系か を，第2軸はラジエータグリルの目立ち度を指標にした軸で あると読み取ることができる。 また, 属性の相関関係の例と して, 図11の右下に描画されている「ラジエータグリル」の 「目立つ」と「丸み」の「角ばり」は布置図上で近くに布置さ れていることから，相関をもつことが読み取れる，よって， これらの属性は 1 軸の「スポーツカー↔乗用車」, 2 軸の 「ラジエータグリルの目立ち度」の中の「ラジエータグリル が目立つスポーツカー系の車」という意味性の中で相関関係 にあることがわかる。また，図11の右上に描画されている 「キャビンとボデー」の「分割型」と「丸み」の「中間」も布置 図上で近くに布置されていることから, 相関をもつことが読 み取れる。

\section{（iii）包含をもつ属性間の意味性の読み取り}

(ii )より,「ラジエータグリル」の「目立つ」と「丸み」の 「角ばり」は1-2軸の布置図より相関関係にあることがわかる. また,（i ）より,「ラジエータグリル」の「目立つ」と「丸み」 の「角ばり」は包含関係にあることもわかる. よって, 包含・ 相関関係同時可視化システムょり, これらの属性は「ラジエー

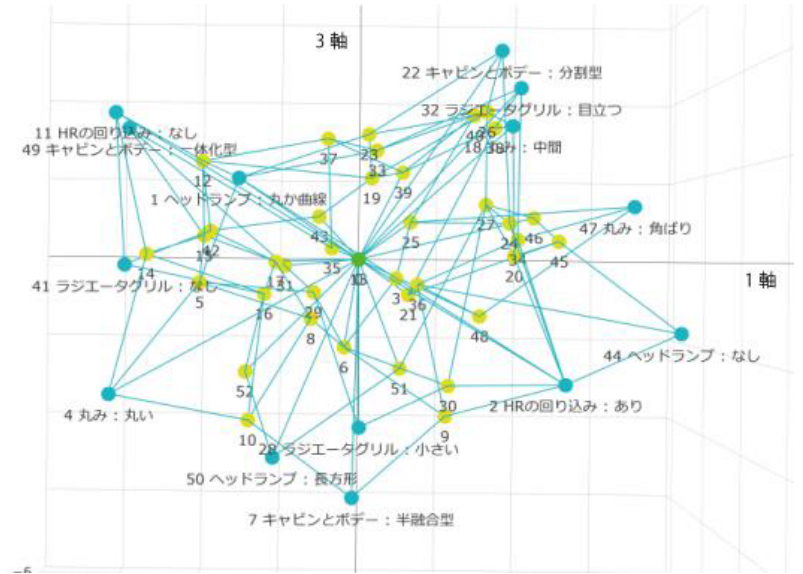

図12 1-3軸の布置図 (自動車の形態要素とイメージ)

タグリルが目立つスポーツカー系の車」という意味性の中, 包含関係をもっていると考えられる。したがって, 包含・相関 関係同時可視化システムによって, 属性間でどのような意味 性の中，包含関係をもつかを検討することができた。次に， $\lceil\mathrm{HL} の$ 回り込み」の「なし」と「キャビンとボデー」の「一体 化型」の2つの属性に着目すると, この2つの属性はハッセ図 より，包含関係をもっていることがわかり，「キャビンと ボデー」の「一体化型」は「HLの回り込み」の「なし」に包 含されていることが読み取れる。しかし，図11の1-2 軸の 布置図より,「HLの回り込み」の「なし」と「キャビンとボデー」 の「一体化型」は近い位置に布置されておらず, 相関をもって いないことがわかる，ここで，カテゴリスコアの1-3軸の布置 図に着目する。 カテゴリスコアの1-3軸の布置図を図12に 示す. 図12より, カテゴリスコア1-3 軸の布置図では「HLの 回り込み」の「なし」と「キャビンとボデー」の「一体化型」は 近い位置（図12の左上）に布置されているため, この2つの 属性は1-3軸の布置図において相関関係にあるといえる。 軸の解釈として, 第 1 軸は先ほどと同じく, スポーッカー系 か乗用車系かを，第3軸はヘッドランプの回り达みのありな しを指標にした軸であると読み取ることができる。よって, 「HLの回り込み」の「なし」と「キャビンとボデー」の「一体

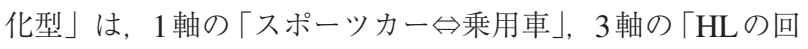

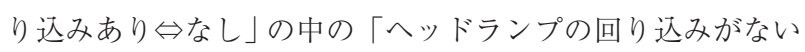
乗用車系の車」という意味性の中, 包含関係をもっていると 考えられる.

以上より, 相関関係の同時可視化システムから, 属性間で どのような意味性の中, 包含関係をもつかを検討できた. これは形式概念分析や数量化理論第正類単体では検討するこ とは難しく，提案手法の有用性を示している.

\section{5. ま と}

本研究では以下に示す成果が得られた。

（1）形式概念分析と数量化理論第而類を組み合わせ，ハッ セ図とカテゴリスコアの布置図を融合させることで, 包含・相関関係の同時可視化手法を提案した. 
（2）既存の形式概念分析や数量化理論第類を用いた分析 結果と, 提案手法を使用した分析結果を比較し, 提案 手法の有用性を検証した.

（3）その結果，本システムの分析結果からしか得られない 包含・相関関係をいくつか得ることができた。また, グラフ上で属性間の包含と意味性を同時に可視化する ことができるため, 形式概念分析, 数量化理論第 III類 をそれぞれ単体で用いて分析を行うよりも容易に情報 を抽出することができた。このことから，本研究で提 案した分析手法は, 数学的に定義された概念に基づき, データ分析を行う新たな手法として，有用性があると 考えることができた

また，今後の課題として以下のことがあげられる.

（1）現在のシステムを用いた提案手法では，入力されるデー 夕の数が多くなるとシステムの処理速度が極めて遅くな るかつ, グラフの概念構造が複雑になり, 可視化が困難 にあるため, 大規模なデータの分析には不向きである. そのため, アルゴリズムの再検討と, グラフの必要な 部分以外を省略し，簡略化して描画する機能をシステム に組み込み，提案手法の再検討を行う必要がある。

（2）現在のシステムでは, 手動で布置図の軸を切り替えて包 含の意味性を模索しているが, この方法だと手間がかか り，分析に時間がかかってしまうので，自動で包含の意 味性を探索する機能をシステムに組み込む必要がある。

（3）本研究では, 属性 (カテゴリ) 間の包含・相関関係に着 目して研究を行ったが, これらとサンプルとの関わりに ついてはまだ検討できていないので, 引き続き研究を行 う必要がある。

\section{参 考 文 献}

［1］藤巻遼平, 森永聡：ビッグデー夕時代の最先端データマイ ニング， NEC技報， 65(2)，pp.81-85，2012.

[2] Kolyshkina, I.: Actuary Australia, Institute of Actuaries of Australia, 90, p.14, 2004.

[3] 酒匂一世, 原田利宣：ラフ集合と形式概念分析を用いた 概念構造可視化システムの開発, デザイン学研究，64(3), pp.11-20, 2017.

４4］澤勢一史，延原肇：大規模画像群のための形式概念分析に 基づく束構造可視化システム, 知能と情報 : 日本知能情報 ファジィ学会誌, 21(1), pp.32-40, 2009.
[5] Zhang, Z., Zhao, J., and Yan, X.: A web page clustering method based on formal concept analysis, MDPI AG, 28, pp.238-239, 2018.

[6] 森繁人, 斎藤等, 伊藤聡久, 関瑞恵 : 数量化理論 III類に よるスギ花粉飛散動態分析, 耳鼻咽喉科臨床, 88(10), pp.1279-1285, 1995.

［7］向日恒喜, 植田真司, 村杉健, 宇井徹雄：人と情報システ ムに関する数量化理論正類による分析, 日本経営工学会, 日本経営工学会誌, 45 (5), pp.472-478, 1994.

［8］長田博泰: 形式概念にもとづく質的分析, 社会情報, 14 (1), pp.19-37, 2004.

［9］澤勢一史，延原肇：概念の接続情報に基づく束構造の複雑 さの定量化, 日本知能情報ファジィ学会, 第27回ファジィ システムシンポジウム, pp.275-278, 2011.

[10］長本田正久, 島田一明：経営のための多変量解析法, 山能 大学出版部刊, pp.139-153, 1977.

［11］島田哲夫, 原田利宣：コンセプトデザイニング - 企画・設計· 評価への科学的アプローチー, 科学技術出版, pp.98-106, 1996.

[12］森典彦，高梨令：ラフ集合の概念による推論を用いた設計 支援，東京工芸大学芸術学部紀要，3，pp.35-38， 1997.

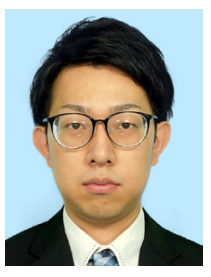

島田 雄生（非会員）

2019 年 和歌山大学システム工学部卒業. 同年, 和歌山大学大学院システム工学研究科 システム工学専攻博士前期課程入学. 現在に 至る。主として, 形式概念分析に関する研究 に従事.

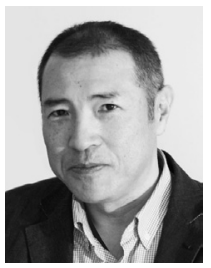

\section{原田 利宣（正会員）}

1996 年 千葉大学大学院自然科学研究科修了. 工学 (博士). マッダ株式会社車両設計部, 日産自動車株式会社デザイン本部を経て, 1997 年度 和歌山大学システム工学部助教授. 2004年度より,同教授，現在に至る。曲線(面) の分析・創成手法開発やラフ集合を中心としたデザイン方法論 の開発に従事. 1996 年 日本デザイン学会研究奨励賞受賞, 2004 年 グッドデザイン賞受賞，2002，2004，2005，2010年 感性工学会出版賞など. 